\title{
PENGARUH PENGETAHUAN KEWIRAUSAHAAN DAN PENDAPATAN ORANGTUA TERHADAP MINAT BERWIRAUSAHA SISWA KELAS XII PEMASARAN SMK NEGERI 7 MEDAN T.A 2018/2019
}

\author{
M. Fachry Nasution 1)*, Sry Melva Panggabean ${ }^{2)}$ \\ 1) Fakultas Ekonomi Universitas Negeri Medan \\ 2) Alumni Fakultas Ekonomi Universitas Negeri Medan \\ ${ }^{1)}$ E-mail: fachry.17011956@gmail.com \\ ${ }^{2)}$ E-mail: lymanroe@ rocketmail.com
}

\begin{abstract}
Penelitian ini bertujuan untuk mengetahui tingkat minat berwirausaha siswa di kelas XII Pemasaran SMK Negeri 7 Medan tahun ajaran 2018/2019. Penelitian ini adalah jenis penelitian Expos-Facto dengan metode kuantitatif.. Populasi dalam penelitian ini seluruh siswa kelas XII Pemasaran SMK Negeri 7 Medan yang terdiri dari 2 kelas. Sampel yang digunakan adalah seluruhnya dengan cara teknik total sampling yang terdiri dari 65 siswa. Instrumen yang digunakan adalah angket bentuk pilihan berganda dan pernyataan dengan menggunakan skala likert. Hasil analisis data perhitungan regresi linear berganda diperoleh persamaan garis linear $\mathrm{Y}=21,267+0,338 \mathrm{X} 1+0,454 \mathrm{X} 2$. Secara parsial pengujian hipotesis dengan menggunakan statistik Uji-t untuk variabel X1 diperoleh thitung 4,209 dengan signifikan $\square=$ 0,000 dimana ttabel sebesar 1,669. Hasil pengujian ini menunjukkan bahwa thitung>ttabel $(4,209>1,669)$ atau sig $\square=0,000<0,05$ dengan kata lain hipotesis diterima. Kemudia untuk variabel X2 diperoleh thitung $>$ ttabel $(5,393>1,669)$ atau sig $\square 0,000<0,05$ dengan demikian hipotesis diterima. Hasil pengujian hipotesis secara simultan diperoleh Fhitung $=56,214$ menunjukkan bahwa Fhitung $>$ Ftabel $(56,214>3,15)$ dengan signifikansi $\square=0,000<0,05$ yang berarti bahwa hipotesis diterima, dimana ada pengaruh yang positif dan signifikan antara pengetahuan kewirausahaan dan pendapatan orangtua terhadap minat berwirausaha siswa kelas XII Pemasaran SMK Negeri 7 Medan tahun ajaran 2018/2019 yang berarti hipotesis ini dapat diterima.
\end{abstract}

Kata Kunci : Pengetahuan Kewirausahaan, Pendapatan Orangtua, dan Minat Berwirausaha. 


\section{PENDAHULUAN}

Seiring bertambahnya jumlah penduduk di Indonesia yang menimbulkan banyak permasalahan, salah satunya adalah kurangnya lapangan pekerjaan. Jika dibandingkan antara lapanganpekerjaan dengan orang yang mencari kerja lebih banyak ditemukan adalah orang yang mencari kerja, sehingga banyak yang tidak mendapatkan peluang untuk bekerja yang mengakibatkan jumlah pengangguran semakin besar dan berdampak pada perekonomian di Indonesia.

Negara Indonesia merupakan salah satu negara yang memiliki jumlah penduduk yang banyak. Pengangguran menjadi salah satu masalah bagi negara berkembang khususnya Indonesia. Pengangguran merupakan produk dari ketidakmampuan pasar kerja dalam menyerap angkatan kerja yang tersedia.

Badan Pusat Statistika (BPS) 2018

(diakses tanggal 04 Mei 2018) mencatat pada bulan Maret 2018, "Jumlah penduduk miskin (penduduk dengan pengeluaran per kapita per bulan di bawah Garis Kemiskinan) di Indonesia mencapai 25,95 juta orang $(9,82 \%)$. Dari 127,07 juta orang yang bekerja, sebesar 7,64\% masuk kategori setengah menganggur dan 23,83\% pekerja paruh waktu". Badan P usat Statistika (BPS) 2018 (di akses tanggal 04 Mei 2018)

Tingkat Pengangguran Terbuka (TPT) di Indonesia pada Februari 2018 mencapai $5,13 \% \quad(6,87$ juta $)$ orang. Dirincikan dari 133,94 juta angkatan kerja sebanyak 127,07 juta bekerja, dengan 87,08 juta orang merupakan pekerja penuh, 30,29 juta pekerja paruh waktu dan 9,70 juta setengah menganggur. Sementara jika dilihat dari tingkat pendidikannya, maka TPT terbesar berada pada Sekolah Menengah Kejuruan (SMK) yang mencapai 8,92\%.

Salah satu cara untuk mengatasi pengangguran di Indonesia adalah dengan melakukan kegiatan kewirausahaan. Pilihan untuk berwirausaha dan menciptakan lapangan pekerjaan berpeluang menghasilkan pendapatan yang lebih besar daripada berkarir menjadi karyawan. Selain itu menjadi wirausaha dapat menyerap tenaga kerja dan mengurangi jumlah pengangguran. Pajak yang dihasilkan dari wirausaha juga dapat meningkatkan perekonomian di Indonesia. Berwirausaha merupakan salah satu faktor pendukung yang menentukan maju mundurnya perekonomian di suatu negara khususnya Indonesia, karena dalam bidang berwirausaha sendiri mempunyai kebebasan untuk berkarya dan mandiri. Seseorang memiliki keinginan dan kemauan serta siap untuk berwirausaha, berarti seseorang itu mampu menciptakan lapangan pekerjaan dan tidak perlu mengandalkan orang lain maupun perusahaanuntuk mendapatkan pekerjaan bahkan dapat membuka lowongan pekerjaan untuk calon pekerja.

Solusi ini di anggap tepat untuk mengatasi pengangguran dengan menciptakan lulusan lembaga pendidikan yang memiliki potensi untuk mengembangkan keterampilan para lulusannya dalam menciptakan usaha mandiri. Pendidikan hendaknya dapat berperan dalam meningkatkan jumlah wirausahawan di Indonesia. SMK sebagai salah satu lembaga pendidikan dan pelatihan diharapkan dapat mendidik siswa untuk menjadi calon-calon wirausahawan melalui pembelajaran kewirausahaan sehingga menghasilkan siswa-siswi yang memiliki pengetahuan kewirausahaan melalui pembelajaran kewirausahaan sehingga menghasilkan siswa-siswi yang memiliki pengetahuan kewirausahaan.

Untuk membentuk manusia yang berjiwa wirausaha dan sekaligus mampu melakukan wirausaha, khususnya pada siswa maka yang seharusnya tertanam terlebih dahulu adalah minat untuk berwirausaha itu sendiri. Ada faktor yang mempengaruhi seseorang untuk berwirausaha, yaitu faktor internal dan eksternal. Faktor internal meliputi hak kepemilikan kemampuan/kompetensi dan intensif, sedangkan faktor eksternal meliputi lingkungan. Menurut Soedjono (dalam Suryana 2014:62) mengemukakan bahwa "Kemampuan afektif mencangkup sikap, nilai, aspirasi, perasaan dan emosi yang semua nya sangat bergantung pada kondisi lingkungan yang ada, maka dimensi kemampuan afektif dan kemampuan kognitif merupakan bagian dari pendekatan kemampuan kewirausahaan”.

Salah satu faktor internal yang mempengaruhi minat berwirausaha adalah pengetahuan berwirausaha itu sendiri. Menurut Suryana (2014:4) "Seorang wirausaha tidak akan berhasil apabila tidak memiliki pengetahuan, kemampuan dan kemauan". Ada kemauan tetapi tidak memiliki kemampuan dan pengetahuan tidak 
akan membuat seseorang menjadi wirausaha yang sukses.

Oleh karena itu, pengetahuan tentang kewirausahaan sangatlah penting. Pengetahuan kewirausahaan juga telah ditanamkan di dunia pendidikan terkhususnya siswa SMK Pemasaran. Namun kenyataan nya banyak juga siswa yang kurang tertarik untuk menjadi seorang wirausaha. Padahal siswa telah dibekali pengetahuan kewirausahaan melalui mata pelajaran kewirausahaan yang di ajarkan. Berikut tabel persentase nilai mata pelajaran kewirausahaan kelas XII Pemasaran SMK Negeri 7 Medan.

\section{Tabel 1}

Persentase Nilai Mata Pelajaran Kewirausahaan Kelas XII PM SMK N 7 Medan

\begin{tabular}{|c|c|c|c|c|c|}
\hline \multirow{2}{*}{ Kelas } & $\begin{array}{c}\text { Jumlah } \\
\text { Siswa }\end{array}$ & \multicolumn{2}{|c|}{$\begin{array}{c}\text { Jumlah Siswa Yang } \\
\text { Memperoleh Nilai Diatas } \\
\text { KKM }\end{array}$} & $\begin{array}{c}\text { Jumlah Siswa Yang } \\
\text { Memperoleh Nilai Dibawah } \\
\text { KKM }\end{array}$ \\
\hline XI PM 1 & 32 siswa & 22 Siswa & $33,8 \%$ & 10 siswa & $15,3 \%$ \\
\hline XI PM 2 & 33 siswa & 21 siswa & $32,3 \%$ & 12 siswa & $18,4 \%$ \\
\hline Jumlah & 65 siswa & 43 siswa & $66,1 \%$ & 22 siswa & $33,7 \%$ \\
\hline
\end{tabular}

Banyak faktor yang mempengaruhi minat berwirausaha siswa diantaranya adalah pengetahuan tentang kewirausahaan sendiri dan keadaan ekonomi keluarga. Keadaan ekonomi keluarga siswa berbeda beda. Dilihat dari pendapatan yang dimiliki orangtua merupakan salah satu faktor eksternal yang dapatmempengaruhi minat berwirausaha siswa.

Bahwasannya dengan ekonomi keluarga yang mencukupi maka keluarga dapat dengan leluasa memfasilitasi anak dalam mengembangkan bakatnya ataupun minatnya. Dan apabila anak diberi fasilitas yang cukup dalam mengembangkan minatnya anak akan lebih percaya diri dalam menjalankan minat tersebut.

Adapun kewirausahaan itu tidak akan terjalankan dengan baik tanpa adanya modal material yang didukung dengan kondisi ekonomi keluarga dan modal intelektual yang berarti pengetahuan yang dimiliki siswa. Berikut tabel persentase pendapatan orangtua siswa kelas XII Pemasaran SMK Negeri 7 Medan. 
Tabel 2

Persentase Pendapatan Orangtua Siswa Kelas XII PM SMK N 7 Medan Per Bulan

\begin{tabular}{|c|c|c|c|}
\hline No & Keterangan & $\begin{array}{c}\text { Jumlah } \\
\text { Siswa }\end{array}$ & $\begin{array}{c}\text { Persentase } \\
(\%)\end{array}$ \\
\hline 1 & $\begin{array}{c}\text { Sangat Tinggi } \\
(>\text { Rp. 3.500.000) }\end{array}$ & 3 & $4,61 \%$ \\
\hline 2 & $\begin{array}{c}\text { Tinggi (Rp. } \\
\text { 2.500.000 - Rp. } \\
3.500 .000)\end{array}$ & 14 & $21,53 \%$ \\
\hline 3 & $\begin{array}{c}\text { Sedang (Rp. } \\
1.500 .000-\mathrm{Rp} . \\
2.500 .000)\end{array}$ & 28 & $43,07 \%$ \\
\hline \multirow[t]{2}{*}{4} & $\begin{array}{c}\text { Rendah (Rp. } \\
1.500 .000)\end{array}$ & 20 & $30,76 \%$ \\
\hline & Jumlah & 65 & $99,97 \%$ \\
\hline
\end{tabular}

Berdasarkan hasil observasi dan wawancara peneliti bersama siswa kelas XII Pemasaran SMK Negeri 7 Medan ternyata masih banyak memilih untuk menjadi pegawai atau karyawan setelah lulus sekolah, dapat dilihat dari tabel dibawah ini:

$$
\text { Gambar } 1.1
$$

Diagram Minat Berwirausaha Siswa Kelas XII PM SMK Negeri 7 Medan

\section{Sales}

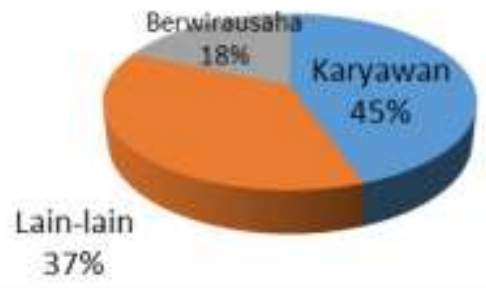

Profesi pegawai atau karyawan dinilai lebih praktis dan menyenangkan daripada berwirausaha. Siswa masih tergantung pada lapangan pekerjaan yang ada. Siswa juga mengaku masih kesulitan dalam menemukan ide untuk berwirausaha dan belum berani karena belum memiliki modal, serta takut pada resiko kegagalan.

\section{TINJAUAN PUSTAKA}

Pengetahuan yaitu hasil dari aktivitas terpenting yang melibatkan otak termasuk dalam ranah kognitif. Dalam ranah kognitif terdapat enam jenjang proses berpikir, keenam jenjang tersebut adalah pengetahuan, pemahaman, penerapan, analisis, sintesis dan peniaian. Pada pembahasan penelitian ini jenjang yang akan dibahas adalah jenjang pengetahuan.

Pengetahuan adalah mengelola seluruh elemen sistem berupa dokumen, basis data, kebijakan dan prosedur lengkap, beserta informasi tentang pengalaman, keahlian, dan kecakapan sumber daya manusia secara individu maupun kolektif.

Dalam kehidupan sehari-hari, masih banyak orang yang menafsirkan dan memandang bahwa kewirausahaan identik dengan apa yang dimiliki dan dilakukan oleh usahawan atau wiraswasta. Namun, pandangan tersebut kurang tepat karena jiwa dan sikap kewirausahaan tidak hanya dimiliki oleh usahawan tetapi juga dimiliki oleh setiap orang yang berpikir secara secara kreatif dan inovatif, misalnya seorang petani, karyawan, pegawai pemerintah, guru, pimpinan proyek, mahasiswa dan lain sebagainya.

Sampai saat ini konsep kewirausahaan masih terus berkembang. Kewirausahaan pada hakikatnya adalah suatu sikap, jiwa dan kemampuan untuk menciptakan sesuatu yang baru dan bernilai serta berguna bagi diri dan orang lain. Kewirausahaan adalah kemampuan kreatif dan inovatif yang dijadikan sebagai dasar, kiat dan sumber daya, untuk mencari peluang menuju sukses.

Menurut Wan Nur, dkk (2015:142) "Entrepreneurship provides space and opportunities for individuals to work on the things they want to explore andcreates opportunities that allow lucrative returns".

Kewirausahaan memberikan ruang dan peluang bagi individu untuk bekerja pada hal-hal yang ingin mereka jelajahi danmenciptakan peluang yang memungkinkan pengembalian yang menguntungkan.

Seorang wirausaha tidak akan berhasil, apabila tidak memiliki pengetahuan, kemampuan dan kemauan. Tetapi apabila hanya ada kemauan tetapi tidak memiliki kemampuan dan pengetahuan maka juga tidak akan membuat seseorang tersebut menjadi wirausaha yang sukses. Begitu juga, apabila wirausaha memilki pengetahuan dan kemampuan tetapi tidak disertai kemauan maka juga tidak akan membuat wirausaha tersebut mencapai kesuksesan.

Pengetahuan saja tidak cukup bagi wirausaha, tetapi juga harus disertai dengan keterampilan. Keterampilan tersebut, dapat berupa keterampilan manajerial, konseptual, memahami, mengerti, berkomunikasi, merumuskan masalah dan cara bertindak, mengatur dan menggunakan waktu dan keterampilan lainnya. Apabila wirausaha hanya memiliki pengetahuan dan keterampilan, hal tersebut tidaklah cukup, tetapi wirausaha harus juga memiliki sikap, motivasi, dan komitmen terhadap pekerjaan yang sedang dihadapinya.

Kompetensi diartikan sebagai pengetahuan, keterampilan, dan kemampuan individu, yang langsung berpengaruh pada hasil, karena wirausaha adalah orang yang selalu berorientasi pada hasil. Pengetahuan kewirausahaan mendukung nilai-nilai wirausaha, terutama bagi siswa-siswi sehingga dapat menumbuhkan jiwa usaha untuk berwirausaha. Pengetahuan kewirausahaan dapat ditingkatkan melalui pendidikan kewirausahaan. 
Pengetahuan kewirausahaan dapat diperoleh melalui pendidikan kewirausahaan. Sejalan dengan hal tersebut, Suryana (2014:2) menyatakan bahwa "Kewirausahaan bukan hanya urusan lapangan, tetapi merupakan disiplin ilmu yang dapat dipelajari dan diajarkan". Hal ini membuktikan bahwa jiwa kewirausahaan itu dapat dipelajari melalui pendidikan formal lebih lanjut.

Pengetahuan kewirausahaan dapat membuka wawasan siswa, bahwa setelah lulus dari sekolah menengah kejuruan, para lulusan tersebut tidak hanya berfikir untuk menjadi job seeker (pencari kerja), namun lebih berfikir untuk menjadi job creator (pencipta lapangan pekerjaan). Dari hal tersebut pastinya dapat lebih bermanfaat bukan hanya bagi diri sendiri, tetapi juga bagi orang lain bahkan bermanfaat untuk membantu program pemerintah yaitu mengurangi tingkat pengangguran dan berhasil menjadi sumber kesejahteraan masyarakat.

Jadi dapat ditarik kesimpulan bahwa pengetahuan kewirausahaan adalah keseluruhan apa yang diketahui tentang segala bentuk informasi melalui pancaindra dan akalnya yang diolah dan berproses dalam ranah kognitif berupa ingatan dan pemahaman tentang suatu usaha untuk membangun suatu value dengan kemampuan dan keberanian mengambil risiko secara rasional dan logis dalam menangani suatu usaha untung peluang menuju sukses.

Kebutuhan manusia tidak terlepas dari berbagai jenis kebutuhan. Dalam mencukupi kebutuhan sehari-hari dan kebutuhan yang lainnya setiap orang memerlukan pekerjaan. Dengan bekerja akan memperoleh pendapatan, apabila pendapatan tersebut dapat mencukupi kebutuhan sehari-hari dan mencukupi kebutuhan rumah tangga lainnya maka keluarga tersebut dikatakan makmur. Pendapatan orangtua adalah suatu tingkat dimana seberapa jumlah pemasukan dari segi materi keluarga tersebut dapat memenuhi kebutuhan, baik memenuhi kebutuhan fasilitas tempat tinggal, kesehatan, harmonisasi antara sesama keluarga dan lingkungan masyarakat.

Pendapatan merupakan seluruh penghasilan baik berupa barang maupun jasa yang dihasilkan masyarakat dalam jangka waktu tertentu atau biasanya dalam satu tahun. Dengan pendapatan tersebut individu dapat membeli barang dan jasa yang dibutuhkan dalam kehidupan sehari-hari. Setiap orang berhak untuk mencari nafkah dalam upaya untuk mencukupi kebutuhan hidupnya.

Pendapatan orangtua adalah bentuk masukan yang diterima oleh ayah dan ibu seperti upah, honorium, keuntungan usaha, dan pendapatan hasil penyewaan suatu barang untuk memenuhi kebutuhan keluarga sehari-hari maupun memenuhi kebutuhan untuk pendidikan anak. Dan untuk pendidikan anak membutuhkan pembiayaan yang tidak angat kecil sehingga membutuhkan suatu pengorbanan karena pendidikan itu di anggap sebagai suatu investasi di masa depan.

Untuk masyarakat yang mempunyai penghasilan yang rendah, mereka berupayaagar hasil dari pekerjaannya dapat untuk memenuhi kebutuhan sehari-hari. Untuk keluarga yang berpenghasilan sedang mereka lebih terarah kepada pemenuhan kebutuhan-kebutuhan pokok yang layak seperti makan, pakaian, perumahan, pendidikan, dan lain-lain. Untuk keluarga yang berpenghasilan tinggi dan bercukupan mereka akan memenuhi segala keinginan yang mereka inginkan termasuk untuk menyekolahan anakanaknya ke jenjang pendidikan yang lebih tinggi. Sedangkan untuk keluarga yang berpendapatan sangat tinggi maka dapat mencukupi seluruh kebutuhan-kebutuhan mereka bahkan masih dapat menabung untuk masa yang akan datang.

Minat merupakan kesadaran yang menyebabkan timbulnya perhatian, bila seorang berminat terhadap sesuatu maka ia akan bersungguh-sungguh dengan penuh perhatian untuk hasil yang baik dari yang diminatinya.

Menurut Slameto (2010:180) "Minat adalah suatu rasa lebih suka dan rasa ketertarikan pada suatu hal atau aktivitas, tanpa ada yang menyuruh. Minat pada dasarnya adalah penerimaan akan suatu hubungan antara diri sendiri dengan sesuatu diluar diri, semakin kuat hubungan tersebut maka semakin besar minat".

$$
\text { Menurut Kartono (dalam }
$$

Lukmayanti 2012: 17) "Minat merupakan momen-momen dari kecenderungan jiwa yang terarah secara intensif kepada suatu obyek yang di anggap paling efektif (perasaan, emosional) yang didalamnya terdapat elemen-elemen efektif (emosi) yang kuat".

Menurut Suryana (2010: 28) "Wirausaha adalah orang-orang yang mempunyai kemampuan melihat dan menilai kesempatan usaha mengumpulkan serta sumber daya yang dibutuhkan guna mengambil keuntungan daripadanya dan mengambil tindakan yang tepat guna memastikan kesuksesan".

$$
\text { Menurut Suryana (2010: }
$$

"Berwirausaha berarti memadukan watak pribadi, keuangan, dan sumber daya". Oleh karena itu berwirausaha merupakan suatu pekerjaan atau karier yang harus bersifat dleksibel dan imajinatif, mampu merencanakan, mengambil resiko, keputusan, dan tindakan untuk mencapai tujuan. Syarat berwirausaha adalah harus memiliki kemampuan untuk menemukan dan mengevaluasi peluang, mengumpulkan sumber-sumber daya yang diperlukan, dan bertindak untuk memperoleh keuntungan dari peluang-peluang tersebut.

Banyaknya pengangguran dapat menimbulkan permasalahan bagi perekonomian di Indonesia. 
Salah satu cara yang dapat mengatasi pengangguran adalah meningkatkan kewirausahaan di negara itu sendiri. Minat berwirausaha merupakan salah satu modal yang perlu ditanamkan pada setiap individu termasuk siswa. Agar nantinya setelah menyelesaikan pendidikannya, mereka memiliki keberanian untuk membuka usaha.

Pengetahuan kewirausahaan merupakan salah satu faktor internal yang mempengaruhi minat berwirausaha. Pengetahuan kewirausahaan merupakan keseluruhan apa yang diketahui tentang segala bentuk informasi melalui pancaindra dan akalnya yang diolah dan berproses dalam ranah kognitif berupa ingatan dan pemahaman tentang suatu usaha untuk membangun suatu value dengan kemampuan dan keberanian mengambil risiko secara rasional dan logis dalam menangani suatu usaha untung peluang menuju sukses.

Dengan pengetahuan kewirausahaan yang didapatkan seseorang dari pembelajaran ataupun sumber lainnya diharapkan dapat memberikan bekal mengenai kewirausahaan yang nantinya dapat dijadikan sebagai bahan pertimbangan seseorang yang melakukan wirausaha atau dapat menumbuhkan minat berwirausaha.

Faktor lain yang dapat mempengaruhi atau mendukung minat berwirausaha adalah kondisi ekonomi keluarga yang dilihat dari pendapatan orangtua siswa tersebut. Pendapatan orangtua adalah bentuk penerimaan yang diterima oleh ayah dan ibu serta melakukan suatu usaha seperti upah, honorium, keuntungan usaha, dan pendapatan hasil penyewaan suatu barang untuk memenuhi kebutuhan keluarga sehari-hari maupun memenuhi kebutuhan untuk pendidikan anak. Ekonomi keluarga sangat berperan dalam mengembangkan minat kewirausahaan siswa, dimana kondisi ekonomi yang tinggi memungkinkan adanya modal material yang dimiliki dan ini merupakan peluang besar. Seseorang yang ingin berwirausaha tidak lepas dari yang namanya modal material, karena modal material merupakan salah satu peluang dalam berwirausaha.

\section{METODE PENELITIAN}

\section{Jenis Penelitian}

Penelitian dilaksanakan di SMK Negeri 7 Medan yang beralamat di Jl. STM No. 12 E Medan Amplas dan dilaksanakan pada Tahun pembelajaran 2018/2019.

Populasi dalam penelitian ini adalah seluruh siswa kelas XII Pemasaran SMK Negeri
7 Medan yang terdiri dari dua kelas. Rincian jumlah siswa dapat dilihat pada tabel berikut:

\section{Tabel 3}

Populasi Siswa Kelas XI Pemasaran SMK Negeri 7 Medan

\begin{tabular}{|c|c|}
\hline Kelas & Jumlah Siswa \\
\hline XII PM 1 & 32 \\
\hline XII PM 2 & 33 \\
\hline Jumlah & 65 \\
\hline
\end{tabular}

Sumber: Tata Usaha SMK Negeri 7 Medan

Menurut Arikunto

(2010:174), penentuan pengambilan sampel yaitu "Apabila subjeknya kurang dari 100 lebih baik diambil semua sehingga penelitiannya merupakan penelitian populasi. Tetapi jika jumlah subjeknya besar (lebih dari 100) dapat diambil antara $10-15 \%$ atau $15-25 \%$ atau lebih".

Sampel dalam penelitian ini menggunakan teknik Total Sampling. Maka yang menjadi sampel dalam penelitian ini adalah seluruh siswa kelas XII Pemasaran.

Uji normalitas merupakan pengujian untuk melihat pola distribusi dari data sampel yang diambil, apakah telah mengikuti sebaran distribusi normal atau tidak. Uji normalitas ini dapat dideteksi dengan menggunakan histogram dan plot norma dan lain-lain. Ketentuannya adalah apabila output histogram menggambarkan bahwa sebaran data yang ada mempunyai distribusi yang normal. Apabila output kurva normal P-plot menggambarkan sebaran data yang ada menyebar merata dan membentuk suatu garis linear (lurus), dapat disimpulkam bahwa data mempunyai distribusi yang normal. Untuk menguji normalitas dalam penelitian ii, yaitu menggunakan grafik normal plot. Dengan menggunakan aplikasi software SPSS. (Ghozali, 2011:160).

Salah satu asumsi dari analisis regresi adalah linearitas. Hal ini dimaksudkan apakah garis regresi antara $\mathrm{X}$ dan $\mathrm{Y}$ membentuk garis linear atau tidak. Uji linearitas digunakan untuk mengetahui apakah masing-masing variabel bebas sebagai prediktor mempunyai hubungan linear atau tidak dengan variabel terikat. Pengambilan keputusan untuk uji linearitas ini dengan cara membandingkan $\mathrm{F}_{\text {hitung }}$ dengan $\mathrm{F}_{\text {tabel }}$. Jika $\mathrm{F}_{\text {hitung }}<\mathrm{F}_{\text {tabel }}$ pada taraf signifikan 5\% maka regresi linear. $F_{\text {hitung }} \geq \mathrm{F}_{\text {tabel }}$ tidak terdapat hubungan linear antara variabel bebas dengan variabel terikat. Dalam penelitian ini pengujian linearitas menggunakan bantuan SPSS. 
Analisis data adalah pengolahan data yang diperoleh dengan menggunakan rumus atau aturan-aturan yang ada sesuai dengan pendekatan penelitian (Arikunto, 2013).

Untuk mengetahui pengaruh $\mathrm{X}_{1}$ (Pengetahuan Kewirausahaan) dan $\mathrm{X}_{2}$ (Pendapatan Orangtua) terhadap Y (Minat Berwirausaha) digunakan regresi berganda. Untuk mengetahui besarnya pengaruh variabel $\mathrm{X}$ terhadap variabel Y digunakan rumus Regresi Linear Berganda oleh Sugiyono (2014:267)

Uji $\mathrm{t}$ digunakan untuk mengetahui koefisien regresi parsial dari model yang digunakan, artinya variabel independen memengaruhi secara parsial (masing-masing) variabel dependen digunakan untuk memengatuhi pengaruh variabel bebas $\left(\mathrm{X}_{1}\right)$ terhadap variabel terikat $(\mathrm{Y})$ dan juga pengaruh variabel bebas $\left(\mathrm{X}_{2}\right)$ terhadap variabel terikat $(\mathrm{Y})$. Rumus yang digunakan untuk menguji masingmasing hipotesis ini adalah dengan rumus uji $\mathrm{t}$ parsial. (hasan, 2006 : 180).

$$
t=\frac{b 1-B i}{S b 1}
$$

Dimana:

$$
\begin{aligned}
\mathrm{T}= & \mathrm{t} \text { hitung } \\
\mathrm{Bi}= & \text { Nilai koefisien kolerasi masing-masing } \\
& \text { variable } \\
\mathrm{Sb}= & \text { standart error masing-masing variabel }
\end{aligned}
$$

Uji $F$ dilakukan untuk mengetahui variabel independen atau bebas memengaruhi secara bersama-sama terhadap variabel dependen. Nilai signifikansi F yang digunakan yaitu kurang dari $5 \%$.

Apabila dari hasil perhitungan diperoleh hasil $F_{\text {hitung }}>F_{\text {tabel }}$ maka dapat disimpulkan bahwa pengetahuan kewirausahaan dan pendapatan orangtua berpengaruh secara simultan terhadap minat berwirausaha siswa kelas XI Pemasaran SMK Negeri 7 Medan dan jika $F_{\text {hitung }} \leq F_{\text {tabel }}$ maka hipotesis ditolak.

Perhitungan determinasi digunakan untuk mengetahui persentase pengaruh variabel bebas $\left(\mathrm{X}_{1}\right.$ dan $\left.\mathrm{X}_{2}\right)$ secara bersama-sama terhadap variabel terikat (Y). Apabila $\mathrm{R}^{2}$ yang diperoleh mendekati 1 maka dapat dikatakan semakin kuat model tersebut menerangkan variabel bebas terhadap variabel terikat, demikian pula sebaliknya $(0<\mathrm{r}<1)$.

Untuk mengetahui besarnya pengaruh pengetahuan kewirausahaan dan pendapatan orangtua terhadap minat berwirausaha siswa kelas XI Pemasaran SMK Negeri 7 Medan maka koefisien determinasi $\mathrm{R}^{2}$ dapat ditemukan dengan rumus (Sudjana, 2012:370):

$$
\mathrm{KD}=\mathrm{R}^{2} \times 100 \%
$$

Keterangan:

$\mathrm{KD}=$ Koefisien determinasi

$\mathrm{R}^{2} \quad=$ Nilai Korelasi

\section{HASIL DAN PEMBAHASAN Deskripsi Hasil Penelitian}

Penelitian dilaksanakan di SMK Negeri 7 MedanJl. STM No. 12 E Medan Amplas dengan populasi sebanyak 65 orang dan menggunakan teknik Total Sampling. Penelitian ini bertujuan untuk mengetahui pengaruh pengetahuan kewirausahaan dan pendapatan orangtua terhadap minat berwirausaha siswa kelas XII Pemasaran SMK Negeri 7 Medan. Data hasil penelitian diperoleh melalui angket pada variabel pengetahuan kewirausahaan, pendapatan orangtua dan variabel minat berwirausaha. Sebelum data dianalisis terlebih dahulu dilakukan uji instrumen kepada siswa diluar sampel untuk mengetahui validitas dan reliabilitas instrumen angket di uji kepada siswa SMK Negeri 6 Medan.

Pengujian validitas dilakukan dengan menggunakan Product Moment dan reliabilitas angket. Penelitian ini dilakukan dengan Cronbach Alpha yang perhitungan nya menggunakan bantuan SPSS 20 dengan ketentuan jika $r_{\text {hitung }}>r_{\text {tabel }}$ maka butir pertanyaan dan pernyataan dianggap valid pada taraf signifikan $(\alpha=0,05)$ dengan jumlah responden 30 orang. Hasil uji coba instrumen angket disajikan pada lampiran. Setelah dilakukan uji coba, penulis menyebarkan angket yang sudah teruji tersebut pada sampel penelitian yang telah ditentukan yaitu sebanyak 65 orang. Data yang diterima akan diolah menggunakan spss 20 .

Dari hasil perhitungan yang dibantu program SPSS versi 20 bahwa angket pengetahuan kewirausahaan berjumlah 25 butir soal yang dinyatakan valid hanya 23 butir soal. Untuk mengetahui item-item pertanyaan angket pada variabel pengetahuan kewirausahaan $\left(X_{1}\right)$ yang telah diuji validitaskan.

Dari hasil uji validitas variabel angket pendapatan orangtua (X2) sebanyak 25 item kepada 30 responden, diperoleh 20 item valid yang memenuhi ketentuan $\mathrm{r}_{\text {hitung }}>\mathrm{r}_{\text {tabel }}$ dengan taraf signifikan 95\% dengahn alpha 5\%. Dengan demikian item tersebut dapat digunakan dalam pengumpulan data penelitian.

Kemudian untuk hasil uji reliabilitas angket variabel pendapatan orangtua (X2) dari 20 item yang valid adalah 0,735 (Dapat dilihat pada lampiran 11). Berikut adalah tabel hasil uji reliabilitas angket pendapatan orangtua (X2) dapat dilihat pada (lampiran 8) taraf signifikan 95\% dengan alpha 5\%. Hal ini menunjukkan 
bahwa instrumen penelitian untuk variabel pendapatan orangtua terbukti reliable untuk digunakan, dimana nilai $\mathrm{r}_{\text {hitung }}>\mathrm{r}_{\text {tabel }} \quad(0,735>$ 0,361).

Penelitian ini memberikan angket kepada 65 siswa/i kelas XII Pemasaran SMKS Negeri 7 Medan.Dari indikator-indikator ini dimunculkan pertanyaan-pertanyaan yang disusun dalam sebuah angket yang disebarkan kepada responden..

\section{Pembahasan Hasil Penelitian Pengetahuan Kewirausahaan (X1) terhadap Minat Berwirausaha ( $Y$}

Dari hasil penelitian yang dilakukan pada variabel Pengetahuan Kewirausahaan (X1) diperoleh thitung variabel pengetahuan kewirausahaan adalah 4,209 sedangkan ttabel untuk taraf signifikansi $95 \%$ atau $\square=5 \%$ adalah 1,669 maka diperoleh $t_{\text {hitung }}>t_{\text {tabel }}$ atau 4,209 > 1,669 dengan nilai signifikan $\square 0,000<0,05$. Maka dapat disimpulkan bahwa pengetahuan kewirausahaan (X1) secara parsial berpengaruh positif dan signifikan terhadap minat berwirausaha (Y) siswa kelas XII Pemasaran SMK Negeri 7 Medan atau hipotesis alternatif $\left(H_{a l}\right)$ diterima.

Hal ini didukung sesuai teori yang dkemukakan Suryana (2013:5) menyatakan bahwa "Secara garis besar modal kewirausahaan dapat dibagi kedalam empat jenis yaitu modal intelektual, modal sosial dan moral, modal mental, serta modal material". Menurut Setiarini (2017:5) Pengetahuan kewirausahaan adalah dasar dari sumber daya kewirausahaan yang terdapat didalam diri individu. Seorang wirausaha tidak akan berhasil apabila tidak memiliki pengetahuan, kemampuan, dan kemauan. Ada kemauan tetapi tidak memiliki pengetahuan dan kemampuan tidak akan membuat seseorang menjadi wirausaha yang sukses.

Hasil penelitian ini didukung oleh Purnomo (2015:106) yang melakukan penelitian berjudul "Pengaruh pengetahuan kewirausahaan dan lingkungan sosial terhadap minat berwirausaha siswa teknik kendaraan ringan SMK Negeri Syegan tahun ajaran 2014/2015". Hasil penelitian menunjukkan bahwa pengetahuan kewirausahaan berpengaruh positif dan signifikan terhadap minat berwirausaha siswa teknik kendaraan ringan SMK Negeri 1 Syegan, hal ini dibuktikan dari nilai $t_{\text {hitung }}$ lebih besar dari $t_{\text {tabel }}(4,821>1,980)$ dan nilai signifikansi $\square$ sebesar 0,000 yang berarti kurang dari $0,05 \quad(0,000<0,05)$. Pengetahuan kewirausahaan mempunyai sumbangan efektif sebesar $23 \%$.

\section{Pendapatan Orangtua (X2) Terhadap Minat Berwirausaha (Y)}

Analisis data untuk menguji hipotesis dengan uji $\mathrm{t}$ menunjukkan nilai thitung variabel pendapatan orangtua adalah 5,393. Sedangkan untuk $\mathrm{t}_{\text {tabel }}$ pada taraf signifikan $95 \%$ atau $\square=$ $5 \%$ adalah 1,669 maka diperoleh $t_{\text {hitung }}>t_{\text {tabel }}$ atau $5,393>1,669$. Berdasarkan perhitungan tersebut, maka dapat diinterpretasikan bahwa pendapatan orangtua mempengaruhi minat berwirausaha siswa. Dengan demikian dapat disimpulkan hipotesis alternatif $\left(H_{a 2}\right)$ diterima, yang menyatakan bahwa terdapat pengaruh yang positif dan signifikan pendapatan orangtua terhadap minat berwirausaha siswa kelas XII Pemasaran SMK Negeri 7 Medan.

Hal ini didukung dengan teori yang dikemukakan oleh Abu Ahmadi (dalam Kadarsih 2013:6) bahwa "Keadaan sosial ekonomi keluarga mempunyai peranan terhadap perkembangan anak-anak, misalnya keluarga yang perekonomiannya cukup, menyebabkan lingkungan material yang dihadapi oleh anak di dalam keluarganya akan lebih luas, sehingga ia dapat kesempatan yang lebih luas didalam memperkenalkan bermacam-macam kecakapan".

Menurut Hajrah, dkk (2016:106) Kondisi ekonomi adalah kondisi seseorang atau keluarga untuk melengkapi kebutuhannya.Kondisi ekonomi orang tua dapat dilihat dengan menganalisis pendapatan keluarga bulanan danbeban total orang tua. Dalam hal inisetiap siswa pasti berasal dariberbedakondisi ekonomi orang tua.

Hasil penelitian ini didukung oleh Nurlaela (2014:200) Pengaruh kondisi ekonomi keluarga dan prestasi belajar terhadap minat berwirausaha siswa SMA". Hasil penelitian menunjukkan bahwa berdasarkan hasil olahan data uji t diperoleh nilai sig sebesar $0,000<\alpha=$ 0,05 . Hal ini menunjukkan bahwa ekonomi orang tua berpengaruh signifikan terhadap minat berwirausaha, hal ini dibuktikan dari nilai $t_{\text {hitung }}$ lebih besar dari $t_{\text {tabel }}(4,028>1,290)$ dan nilai signifikansi $\square$ sebesar 0,000 yang berarti kurang dari $0,05(0,000<0,05)$.

\section{Pengetahuan Kewirausahaan (X1) dan Pendapatan Orangtua (X2) Terhadap Minat Berwirausaha (Y) \\ Berdasarkan hasil uji koefisien regresi} secara bersama-sama (simultan) (uji F) diperoleh fhitung untuk pengetahuan kewirausahaan dan pendapatan orangtua terhadap minat berwirausaha siswa sebesar 56,214 dan dibandingkan dengan ftabel didasarkan pada $\mathrm{dk}$ pembanding $=\mathrm{k}$ dan $\mathrm{dk}$ penyebut $=(\mathrm{n}(\mathrm{k}-1)$ pada taraf signifikan $95 \%$ atau $\square=5 \%$ maka diperoleh pembanding 2 dan dk penyebut 62 , maka diperoleh sebesar 3,15. Dengan kata lain $f_{\text {hitung }}>f_{\text {tabel }}$ yaitu $56,214>3,15$. Dengan 
demikian dapat disimpulkanhipotesis alternatif $\left(H_{a 3}\right)$ diterima, yang menyatakan bahwa terdapat pengaruh yang signifikan antara pengetahuan orangtua dan pendapatan orangtua terhadap minat berwirausaha siswa kelas XII SMK Negeri 7 Medan.

Hal ini juga didukung dengan teori yang dikemukakan oleh Stewart et al (dalam Koranti 2013:2) menyatakan bahwa tumbuhnya minat berwirausaha dipengaruhi oleh berbagai faktor yang melibatkan berbagai faktor internal, faktor eksternal dan faktor kontekstual. Faktor internal yang berasal dari dalam diri dapat berupa sifatsifat personal, sikap kemauan dan kemampuan. Faktor eksternal berasal dari luar diri pelaku entrepreneur yang dapat berupa unsur dan lingkungan sekitar seperti lingkungan keluarga, lingkungan dunia usaha, lingkungan fisik, lingkungan sosial ekonomi dan lain-lain. Hal ini dibuktikan dari nilai $t_{\text {hitung }}$ lebih besar dari $t_{\text {tabel }}$ $(5,224>1,471)$ dan nilai signifikansi $\square$ sebesar 0,000 yang berarti kurang dari $0,05(0,000<$ $0,05)$.

Dari hasil penelitian dan pengolahan data diperoleh bahwa persentase sumbangan variabel bebas, yaitu pengetahuan kewirausahaan dan pendapatan orangtua terhadap minat berwirausaha sebesar $64,5 \%$ sedangkan sisanya sebesar 35,5\% dipengaruhi oleh variabel lain diluar penelitian.

\section{KESIMPULAN DAN SARAN Kesimpulan}

Berdasarkan hasil pengujian dan pembahasan terhadap data hasil penelitian yang telah dikumpulkan mengenai pengaruh pengetahuan kewirausasahaan dan pendapatan orangtua terhadap minat berwirausaha siswa kelas XII Pemasaran SMK Negeri 7 Medan maka dapat diperoleh kesimpulan sebagai berikut : (1) Adanya pengaruh positif dan signifikan antara pengetahuan kewirausahaan $\left(\mathrm{X}_{1}\right)$ dan Minat Berwirausaha siswa kelas XII Pemasaran SMK Negeri 7 Medan (Y), yaitu dilihat dari $t_{\text {hitung }}>t_{\text {tabel }}(4,209>1,669)$ dan nilai signifikansi $0,000<0,05$. (2) Adanya pengaruh positif dan signifikan antara pendapatan orangtua (X2) dan Minat Berwirausaha siswa kelas XII Pemasaran SMK Negeri 7 Medan (Y), yaitu dilihat dari $t_{\text {hitung }}>t_{\text {tabel }}(5,393>1,669)$ dan nilai signifikan $(0,000<0,05)$. (3) Adanya pengaruh positif dan signifikan antara pengetahuan kewirausahaan $\left(\mathrm{X}_{1}\right)$, dan pendapatan orangtua (X2) terhadap minat berwirausaha siswa kelas XII Pemasaran SMK Negeri 7 Medan (Y), yaitu Fhitung > Ftabel $(56,214>3,15)$, dengan nilai signifikan $\alpha 0,000<0,05$.

\section{Saran}

Berdasarkan pengamatan peneliti selama melaksanakan penelitian pada siswa kelas XII Pemasaran SMK Negeri 7 Medan, peneliti memberikan saran sebagai berikut: (1) Dengan adanya pengaruh pengetahuan kewirausahaan terhadap minat berwirausaha maka pengetahuan siswa terhadap kewirausahaan perlu dipertahankan karena termasuk dalam kategori baik melalui peningkatan proses pembelajaran kewirausahaan di sekolah dan butuh dukungan dari semua pihak sekolah seperti pengajar atau guru yang memberikan pengaktualisasian sikap dan perilaku wirausaha, menerapkan jiwa kepemimpinan sampai merencanakan dan mengelola usaha kecil/mikro. (2) Sehingga dapat menciptakan lapangan pekerjaan dan hasilnya berguna bagi orang lain. (3) Dengan adanya pengaruh pendapatan orangtua terhadap minat berwirausaha siswa maka peran orangtua selaku pendukung dan penyedia modal material haruslah lebih peka atau mengerti dengan perkembangan siswa yang mengarah pada minat yang dimiliki siswa tersebut.

Mengingat hasil penelitian pengetahuan kewirausahaan dan pendapatan orangtua yang berpengaruh positif dan signifikan terhadap minat berwirausaha siswa maka ada perlunya untuk dikembangkan kembali guna menghasilkan penelitian yang lebih baik lagi dengan mempertimbangkan variasi dari sampel yang lain.

\section{REFERENSI}

Adhimursandi, Doddy. 2016. Faktor-Faktor Yang Mempengaruhi Niat Kewirausahaan. Jurnal Ekonomi Dan Manajemen, Vol.13 (1) ISSN : 25281127

Alma, Buchari. 2010. Kewirausahaan. Bandung: Alfabeta

Ambarsari, Desta. 2016. Pengaruh Prestasi Praktik Kerja Industri Dan Hasil Belajar Kewirausahaan Terhadap Minat Berwirausaha Siswa Kelas XII Akuntansi SMK Negeri 25 Jakarta. Jurnal Ilmiah Econosains. Vol.14 No. 1 ISSN 2252-8490

Anggraeni, Betty. 2015. Pengaruh Pengetahuan Kewirausahaan dan Lingkungan Keluarga Terhadap Minat Berwirausaha Siswa SMK: Jurnal. Pendidikan

Ekonomi Dinamika Pendidikan, 10 (1). $42-52$

Arikunto, Suharsimi. 2013. Prosedur Penelitian Suatu Pendekatan Praktik. Jakarta: Rineka Cipta

Asmani, Jamal Ma'mur. 2011. Sekolah Entrepreneur. Yogyakarta: Harmoni

Badan Pusat Statistik. 2017. Tingkat Pengangguran Terbuka (TPT) . Tersedia 
di

https://www.bps.go.id/pressrelease/2017/1

1/06/1377/agustus-2017- tingkat-

pengangguran-terbuka-tpt-sebesar-5-50persen.html

. 2017. Persentase Penduduk Miskin.

Tersedia di

https://www.bps.go.id/pressrelease/2018/0

1/02/1413/persentase- penduduk-

miskin-september-2017-mencapai-10-12persen.html

Fahmi, Irham. 2014. Kewirausahaan Teori, Kasus Dan Solusi. Bandung. Alfabeta

Ghozali, Imam. 2011. Analisis Multivariate Menggunakan SPSS. Semarang : BP UNDIP

Hajrah, dkk. 2016. Effect of Entrepreneurial Education and Economic Conditionof Parents towards an Entrepreneurship Attitudes through the Entrepreneurship Interest. IOSR Journal of Business and Management (IOSR-JBM) e-ISSN: 2278487X, p-ISSN: 2319-7668. Volume 18, Issue 6 .Ver. I (Jun. 2016), PP 105-110 www.iosrjournals.org

Hasan, Iqbal. 2006. Analisis Data Penelitian dengan Statistik. Jakarta: Bumi Aksara

Hendro. 2011. Dasar-dasar Kewirausahaan. Jakarta: Penerbit Erlangga

Husna,dkk. 2015. "Pengaruh Kepribadian dan Mata Kuliah terhadap Minat Berwirausaha Mahasiswa Penerima Dana Program Mahasiswa wirausaha (PMW) Di Fakultas Universitas Bung Hatta". E-jurnal Apresiasi Ekonomi, ISSN, Vol 3, No 2 Hal 167-171

H.A. Rusdiana. 2014. Kewirausahaan Teori dan Praktik. Bandung: Cv Pustaka Setia

Kadarsih, retno. 2013. Faktor-Faktor Yang Mempengaruhi Minat Berwirausaha Pada Mahasiswa Program Studi Pendidikan Ekonomi FKIP UNS. Junal Pendidikan Ekonomi. Vol. 2 No.1

Kurniasih,Suci. 2015. Pengaruh Efikasi Diri dan Minat Berwirausaha Terhadap Prestasi Belajar Kewirausahaan Siswa Kelas XI Jurusan Teknik Komputer dan jaringan SMK Tritech Informatika Medan T.P 2014/2015. Skripsi. Unimed

Kusumajanto. 2015. The Role of Entrepreneurship Education and Self Efficacy in Shaping Student Interest in Doing Entrepreneurship. European Journal of Business and Management. ISSN 2222-1905 (Paper) ISSN 2222-2839 (Online) Vol.7, No.28, 2015

Lukmayanti, Arista. 2012. Hubungan Efikasi Diri Dengan Minat Berwirausaha Siswa Kelas XII Program Keahlian Jasa Boga Di SMK Negeri 6 Yogyakarta. Skripsi. UNY. Diakses Dari
Https://Core.Ac.UK/Download/Pdf//1106 6641.Pdf (20 Maret 2018)

Mariatun. 2017. Pengaruh Efikasi Diri Dan Pengetahuan Kewirausahaan Terhadap Minat Berwirausaha Mahasiswa Pendidikan Ekonomi Tahun Angkatan 2012 Fakultas Ekonomi Universitas Negeri Medan. Skripsi. Fakultas Ekonomi Universitas Negeri Medan.

Muslihuddin dan Ilminiati. 2017. "Pengaruh Efikasi Diri dan Pendapatan Terhadap Minat berwirausaha Siswa SMK (Al-Madina)". Jurnal Media Teknik \& $\quad$ Sistem Industri, Vol 1, HAL 4149

Pratama, Angga. 2017. Pengaruh Lingkungan Keluarga, Efikasi Diri, Dan Pengetahuan Kewirausahaan Terhadap Minat Berwirausaha Pada Mahasiswa Fakultas Ekonomi Universitas Negeri Medan. Skripsi. Fakultas Ekonomi Universitas Negeri Medan.

Ridwan. 2009. Pengukuran Tingkat Pendidikan Formal. $\quad$ http://ridwanbelitung.blogspot.co.id/2009/10. (Diakses pada 20 Maret 2018)

Simanungkalit, Eva Natalia. 2016. Pengaruh Pengetahuan Kewirausahaan, Self Efficacy, dan Karakter Wirausaha Terhadap Minat Berwirausaha pada siswa kelas XISMK Negeri 1 Pantai Cermin. Skripsi. Fakultas Ekonomi Universitas Negeri Medan.

Sinulingga, Priskila Debora. 2010. Pengaruh Pendapatan Orang tua Terhadap

Motivasi Belajar Siswa Di Yayasan Perguruan Swasta SMK Bersama Brastagi Tahun Ajaran 2009/2010.

Skripsi. Fakultas Ekonomi Universitas Negeri Medan.

Sitorus, Fitriyani. 2017. Pengaruh Gaya Hidup Dan Pendapatan Orangtua

Terhadap Pola Konsumsi Mahasiswa Urban Prodi Pendidikan Tata Niaga Stambuk2015 Fakultas Ekonomi Universitas Negeri Medan. Skripsi. Fakultas Ekonomi Universitas Negeri Medan.

Slameto. 2010. Belajar \& Faktor-Faktor Yang Mempengaruhi. Jakarta : Rineka Cipta

Sugiono. 2012. Metode Penelitian Pendidikan Pendekatan Kuantitatif, Kualitatif, dan $R \& D$. Bandung: Alfabeta . 2014. Metode Penelitian (Pendekatan Kuantitatif, Kualitatif, dan $R \& D)$. Bandung: Alfabeta

Suryana. 2006. Kewirausahaan Pedoman Praktis: Kiat dan Proses Menuju Sukses Edisi 3. Jakarta : Salemba Empat 
2010. Kewirausahaan: Pedoman, Praktis, Kiat Dan Proses Menuju Sukses. Jakarta: Salemba Empat

2011. Kewirausahaan: Pedoman, Praktis, Kiat Dan Proses Menuju Sukses. Jakarta: Salemba Empat

2014. Kewirausahaan Kiat dan Proses Menuju Sukses. Bandung: Salemba Empat

Talambanua, Herdyyati. 2014. Pengaruh Pendidikan Orangtua Dan Pendapatan Orangtua Terhadap Prestasi Belajar Ekonomi Siswa Kelas X IPS SMA Negeri 2 Kabanjahe Tahun Pelajaran 2013/2014. Skripsi. Fakultas Ekonomi Universitas Negeri Medan.

Wan Nur. 2015. Impact of Entrepreneurship Education on the Entrepreneurial Intentions of Students in Technical and Vocational Education and Training Institutions (TVET) In Malaysia. International Education Studies; Vol. 8, No. 12; 2015 ISSN 1913-9020 E-ISSN 1913-9039. Published by Canadian Center of Science and Education.

Yulianingsih, Pina. 2013. "Hubungan Pengetahuan Kewirausahaan dan Persepsi Peluang Kerja di Bidang Akuntansi dengan Minat Berwirausaha". Jurnal Pendidikan UNS, Vol 2, No.1 Hal 131-145 